\title{
Soil carbon dioxide emission associated with soil porosity after sugarcane field reform
}

\author{
Luma Castro de Souza ${ }^{1} \cdot$ Carolina Fernandes $^{1}$. \\ Mara Regina Moitinho ${ }^{1}$. Elton da Silva Bicalho ${ }^{1}$. \\ Newton La Scala Jr${ }^{1}$
}

Received: 2 January 2018 / Accepted: 2 March 2018 /Published online: 21 March 2018

(C) Springer Science+Business Media B.V., part of Springer Nature 2018

\begin{abstract}
This study aimed to characterize soil carbon dioxide $\left(\mathrm{CO}_{2}\right)$ emission associated with soil pore distribution in an Oxisol and Ultisol under chiseling in the planting row and in total area for sugarcane (Saccharum officinarum) cultivation. The experimental design was a large paired-plot design. Treatments consisted of chiseling in the planting row (CPR) and chiseling in total area (CTA) in an Oxisol and Ultisol. Soil $\mathrm{CO}_{2}$ emission, soil temperature, and soil moisture were assessed over 12 days in the Oxisol and 11 days in the Ultisol at a depth of $0-0.10 \mathrm{~m}$. Organic carbon associated with minerals (OCAM) and particulate organic carbon (POC) were also assessed. OCAM, pore class C2 $(0.05 \leq$ $\phi<0.1 \mathrm{~mm}$ ), soil moisture, and soil temperature explained 72 and $53 \%$ of the variability of soil $\mathrm{CO}_{2}$ emission in $\mathrm{CPR}$ and CTA, respectively. In the Ultisol, pore class $\mathrm{C} 1(\phi \geq$ $0.1 \mathrm{~mm}$ ) and OCAM explained $82 \%$ of the variability of soil $\mathrm{CO}_{2}$ emission in CPR. In CTA, soil moisture, OCAM, and POC explained $67 \%$ of the variability of soil $\mathrm{CO}_{2}$ emission. In the Oxisol, CPR and CTA affected soil structure, causing changes in both soil porosity and soil $\mathrm{CO}_{2}$ emission. In the Oxisol, the lowest average value of soil $\mathrm{CO}_{2}$ emission $\left(2.8 \mu \mathrm{mol} \mathrm{m} \mathrm{m}^{-2} \mathrm{~s}^{-1}\right)$ was observed in CPR whereas its highest value (3.4 $\mu \mathrm{mol} \mathrm{m} \mathrm{m}^{-2} \mathrm{~s}^{-1}$ ) was observed in CTA. In the Ultisol, soil tillage (CPR and CTA) did not affect soil $\mathrm{CO}_{2}$ emission. These results indicate that the intensity of soil tillage in more clayey textured soils favors soil $\mathrm{CO}_{2}$ emission possibly due to a higher carbon availability for microbial activity when compared to more sandy textured soils. A less intensive soil tillage can be considered as an efficient strategy to reduce soil $\mathrm{CO}_{2}$ emission and hence soil organic carbon losses. Thus, this management strategy proved to be efficient in terms of mitigating greenhouse gas emissions, reducing the contribution of agriculture to global climate change.
\end{abstract}

Luma Castro de Souza

lumasouza30@hotmail.com

1 Faculdade de Ciências Agrárias e Veterinárias, UNESP Universidade Estadual Paulista, Via de Acesso Prof. Paulo Donato Castellane, s/n, Jaboticabal, SP 14884-900, Brazil 
Keywords Carbon $\cdot$ Pore distribution $\cdot$ Chiseling $\cdot$ Soil temperature $\cdot$ Soil moisture

\section{Introduction}

Agriculture is an important source of $\mathrm{CO}_{2}$ emission to the atmosphere (IPCC 2014), standing out agricultural practices related to changes in land use and soil management that contribute to increasing its concentrations (Cerri et al. 2007; Iamaguti et al. 2015). Carbon dioxide is one of the greenhouse gases that have contributed the most to the additional greenhouse effect over the last 200 years (IPCC 2014). In this sense, soil $\mathrm{CO}_{2}$ emission process is associated with the microbial activity, root respiration, plant residue decomposition, and soil organic matter oxidation (Lal 2009). This process is influenced by soil texture, soil structure, soil temperature, and soil moisture (Ussiri and Lal 2009).

Agricultural practices affect soil physical, chemical, and biological attributes (La Scala et al. 2006; Schwartz et al. 2010). In fact, many studies have assessed soil $\mathrm{CO}_{2}$ emission in agricultural areas and observed that soil attributes such as macro and microporosity (Panosso et al. 2011), organic matter (Lal 2009), and organic carbon (Costa et al. 2008; Lal 2009) can directly affect the emission dynamics since these soil attributes control $\mathrm{CO}_{2}$ production in the soil and its transport to the atmosphere.

Soil tillage systems, such as the conventional tillage, contribute to the increased $\mathrm{CO}_{2}$ emission to the atmosphere (La Scala et al. 2006; Iamaguti et al. 2015). In this sense, soil disaggregation due to the disturbance caused by tillage interferes with soil $\mathrm{CO}_{2}$ emission. Considering that, a less intense soil tillage such as the reduced tillage and no-tillage systems in agricultural production areas has been replacing more intense soil tillage systems such as the conventional tillage (Mazurana et al. 2011). Therefore, studies on the use of agricultural practices with less soil mobilization are promising in reducing soil $\mathrm{CO}_{2}$ emission due to soil disaggregation. Thus, chiseling in the planting row stands out as an alternative to the chiseling in total area aiming at reducing soil $\mathrm{CO}_{2}$ emission.

Chiseling promotes soil disaggregation at a depth of $30 \mathrm{~cm}$. In this operation, the soil is moved sideward, forward, and upward, favoring soil aggregate rupture and the exposure of the previously protected organic carbon, creating an environment with a good oxygenation for microbial activity. Carbon is a source of energy for microorganisms and its decomposition favors carbon loss from soil to the atmosphere. When studying soil $\mathrm{CO}_{2}$ flux after plowing and chiseling, Teixeira et al. (2010) observed that the soil submitted to disk plow and disk harrow emitted a higher value of $\mathrm{CO}_{2}\left(260.7 \mathrm{~g} \mathrm{CO}_{2} \mathrm{~m}^{-2}\right)$ over a 14-day assessment period when compared to the soil submitted to chiseling without declodding roller $\left(82.3 \mathrm{~g} \mathrm{CO}_{2} \mathrm{~m}^{-2}\right)$.

According to Mangalassery et al. (2013), studies on $\mathrm{CO}_{2}$ emission dynamics associated with soil pore distribution are incipient in Oxisols and Ultisols. These authors observed that both texture and aggregate size influences soil $\mathrm{CO}_{2}$ emission to the atmosphere. This fact is important to understand how agricultural operations that disturb soils with a lesser intensity have a direct impact on $\mathrm{CO}_{2}$ emission. Different pore characteristics (size, continuity, and shape) interfere with gas transport (Luo et al. 2010) and soil microbial activity (Mangalassery et al. 2013). In its turn, these pore characteristics are affected by soil texture (Mooney and Morris 2008) and agricultural activities related to soil management (Zhou et al. 2008).

This study tests the hypothesis that chiseling in the planting row and in total area interfere directly with soil structure, altering its porosity and causing changes in soil $\mathrm{CO}_{2}$ emission. Thus, the aim of this study was to characterize soil $\mathrm{CO}_{2}$ emission associated with pore 
distribution in an Oxisol and Ultisol under chiseling in the planting row and in total area for sugarcane (Saccharum officinarum) cultivation.

\section{Material and methods}

\subsection{Characterization of the study areas}

The experiment was carried out in two agricultural areas with a distance of $27 \mathrm{~km}$ between each other. The first area was located in Guariba, SP, Brazil, at the geographical coordinates of $21^{\circ} 24^{\prime} \mathrm{S}$ and $48^{\circ} 12^{\prime} \mathrm{W}$, with an average altitude of $618 \mathrm{~m}$ and soil characterized as an Oxisol. The second area was located in Monte Alto, SP, Brazil, at the geographical coordinates of $21^{\circ}$ $15^{\prime} \mathrm{S}$ and $48^{\circ} 25^{\prime} \mathrm{W}$, with an average altitude of $735 \mathrm{~m}$ and soil characterized as an Ultisol.

Regional climate is classified as Aw according to the Köppen classification, indicating a mesothermal region with a dry winter and temperatures for the warmest and coldest months exceeding 22 and $18{ }^{\circ} \mathrm{C}$, respectively. The average annual precipitation is $1400 \mathrm{~mm}$, concentrated from October to March and a dry season between April and September. Both areas were destined for mechanized sugarcane production for more than 20 years.

Soil texture characterization was performed by means of particle size analysis in the layer of 0.0-0.10 m, as in Claessen (1997). Concentrations of clay, sand, and silt were 550, 392, and $58 \mathrm{~g} \mathrm{~kg}^{-1}$, respectively, in the Oxisol and 130, 809, and $61 \mathrm{~g} \mathrm{~kg}^{-1}$, respectively, in the Ultisol. Organic carbon content (OC) was, on average, 17.94 and $7.00 \mathrm{~g} \mathrm{~kg}^{-1}$ in the Oxisol and Ultisol, respectively. The Oxisol presented a soil bulk density (Ds) of $1.24 \mathrm{~g} \mathrm{~cm}^{-3}$, mean weight diameter of aggregates (MWD) of $3.46 \mathrm{~mm}$, total porosity (Pt) of $0.53 \mathrm{~m}^{3} \mathrm{~m}^{-3}$, macroporosity (Macro) of $0.15 \mathrm{~m}^{3} \mathrm{~m}^{-3}$, and microporosity (Micro) of $0.38 \mathrm{~m}^{3} \mathrm{~m}^{-3}$. In its turn, the Ultisol presented a Ds of $1.71 \mathrm{~g} \mathrm{~cm}^{-3}$, MWD of $1.72 \mathrm{~mm}$, Pt of $0.32 \mathrm{~m}^{3} \mathrm{~m}^{-3}$, Macro of $0.07 \mathrm{~m}^{3} \mathrm{~m}^{-3}$, and Micro of $0.25 \mathrm{~m}^{3} \mathrm{~m}^{-3}$.

The Oxisol area is located close to a sandstone-basalt transition, with sandstone from Rio do Peixe Valley, old Bauru Group, Adamantina Formation, and basalt from Serra Geral Formation (IPT 1981). The Ultisol geology is a sandstone from Rio do Peixe Valley, old Bauru Group, Adamantina Formation. The values of kaolinite $(\mathrm{Kt})$ to gibbsite $(\mathrm{Gb})$ ratio were 0.50 and 0.65 , and the contents of iron oxide extracted by dithionite-citrate-bicarbonate $\left(\mathrm{Fe}_{\mathrm{d}}\right)$ were 80.32 and $18.5 \mathrm{~g} \mathrm{~kg}^{-1}$ for Oxisol and Ultisol, respectively (Jackson 1985; Mehra and Jackson 1960).

\subsection{Experimental design and tillage activities conducted in the areas}

The experimental design was a large paired-plot design (Perecin et al. 2015; Souza et al. 2017) with treatments consisting of chiseling in the planting row (CPR) and chiseling in total area (CTA). Before soil tillage, the mechanical removal of sugarcane ratoon was conducted in the Oxisol area in November 2014 by using a mechanical ratoon eliminator; in the Ultisol area, this agricultural practice was conducted in January 2015 using $4 \mathrm{~L} \mathrm{ha}^{-1}$ of glyphosate (N-(phosphonomethyl)glycine). Soil correction was performed in December 2014 in the Oxisol area using $1.5 \mathrm{t} \mathrm{ha}^{-1}$ of lime and $1 \mathrm{t} \mathrm{ha}^{-1}$ of gypsum $\left(\mathrm{CaSO}_{4} 2 \mathrm{H}_{2} \mathrm{O}\right)$; in the Ultisol area, $3 \mathrm{t} \mathrm{ha}^{-1}$ of lime and $1 \mathrm{t} \mathrm{ha}^{-1}$ gypsum were applied in January 2015.

CPR and CTA were performed in the Oxisol on January 31, 2015, with a soil moisture of $0.18 \mathrm{~g} \mathrm{~g}^{-1}$, and in the Ultisol on February 17,2015 , with a soil moisture of $0.11 \mathrm{~g} \mathrm{~g}^{-1}$. In both areas, 
soil moisture was measured at a depth of $0-0.12 \mathrm{~m}$. CPR was conducted by means of a chisel plow with two rollers and two pairs of tynes spaced at $1.5 \mathrm{~m}$ considering the sugarcane spacing planting. The distance between tynes of each pair was $0.50 \mathrm{~m}$. CTA was conducted using a chisel plow with two rollers and five tynes spaced at $0.50 \mathrm{~m}$. For both chisel plows, the tyne length was $0.8 \mathrm{~m}$ with points of $0.25-\mathrm{m}$ long and 0.04-m wide, allowing a working depth of $0.30 \mathrm{~m}$.

The experimental areas had approximately 10 ha (Oxisol) and 9 ha (Ultisol) and were divided into 20 plots with sizes of approximate 0.5 ha for the Oxisol and 0.45 ha for the Ultisol. These 20 plots were equally divided into two tillage treatments, i.e., chiseling in the planting row and in total area for both soils.

\subsection{Determination of soil attributes to characterize the study area}

Soil samples were collected after chiseling operations at a depth of $0.0-0.10 \mathrm{~m}$. Disturbed soil samples were collected using a Dutch auger and used for determining organic carbon associated with minerals (OCAM) and particulate organic carbon (POC) (Cambardella and Elliott 1992). Undisturbed soil samples were collected using an Uhland auger and volumetric rings $(0.05 \times 0.05 \mathrm{~m})$ and used for determining macroporosity (Macro) and microporosity (Micro) (Claessen 1997), in addition to pore size distribution. Two samples were collected at each plot aiming at characterizing the study area: one in the sugarcane row and another between rows (Table 1), totaling 20 sample points at each of the 10 plots.

Pore size distribution was determined by the relation between the tension $(0,30,60$, and $80 \mathrm{~cm}$ of water column) of water retained in capillary tubes and the pore diameter, as shown in Eq. (1):

$$
d=\frac{0.3}{h}
$$

where $d$ is the pore diameter $(\mathrm{cm})$ and $h$ is the height of water column $(\mathrm{cm})$ equivalent to the applied tension (Brady and Weil 2013). The volume $\left(\mathrm{m}^{3} \mathrm{~m}^{-3}\right)$ equivalent to the pore diameter at each applied tension was obtained by the difference between the volume of water corresponding to the previously applied tension and the volume corresponding to the applied tension divided by the total volume of the sample. Thus, four pore classes were determined, two of them corresponded to the macropores, i.e., $\mathrm{C} 1(\phi \geq 0.1 \mathrm{~mm})$ and $\mathrm{C} 2(0.05 \leq \phi<0.1 \mathrm{~mm})$, and the other two corresponded to the micropores, i.e., $\mathrm{C} 3(0.0375 \leq \phi<0.05 \mathrm{~mm})$ and $\mathrm{C} 4(\phi<0.0375 \mathrm{~mm})$.

\subsection{Assessment of soil $\mathrm{CO}_{2}$ emission, soil temperature, and soil moisture}

For the assessment of soil $\mathrm{CO}_{2}$ emission, 40 points (20 points in CPR and 20 points in CTA) at minimum distances of $5 \mathrm{~m}$ were chosen in each experimental area and PVC collars were inserted into

Table 1 Multiple regression model of the average soil $\mathrm{CO}_{2}$ emission as a function of soil attributes in the chiseling in the planting row (CPR) in the Oxisol

\begin{tabular}{lccrr}
\hline Attribute & Parameter & SE & $p$ & $R^{2}$ \\
\hline Intercept & -6.5844 & 1.86209 & 0.0054 & 0.5595 \\
OCAM & 0.61845 & 0.12426 & 0.0006 & 0.7190 \\
C2 & 33.82357 & 14.19456 & 0.0384 & 0 \\
\hline
\end{tabular}

$\mathrm{SE}=$ standard error of the parameter estimation; $R^{2}=$ coefficient of determination; OCAM = organic carbon associated with minerals; C2 $(0.05 \leq \phi<0.1 \mathrm{~mm})$ 
the soil of the sugarcane row and between rows. PVC collars were inserted into the soil before and immediately after chiseling in the planting row and in total area at the same positions since each point was georeferenced. Soil $\mathrm{CO}_{2}$ emission values were obtained from the average emissions assessed in the sugarcane row and between rows. In the Oxisol area, one measurement was conducted before chiseling (January 18, 2015) and 10 measurements after chiseling over a period of 12 days (February $1,2,3,5,6,7,8,10,11$, and 12, 2015). In the Ultisol area, one measurement was also performed before chiseling (February 1, 2015) and 10 after chiseling over a period of 11 days (February 19, 20, 21, 22, 23, 24, 26, 27, and 28 and March 1, 2015).

Assessments were carried out in the morning from 7:00 to 9:00 h. Soil $\mathrm{CO}_{2}$ emission varies within the same day according to temperature variations mainly due to air temperature that influences soil temperature. Other studies designed to assess soil $\mathrm{CO}_{2}$ emission over the days were also conducted in the same period so that the assessments could start and finish with small soil temperature fluctuations (Panosso et al. 2011; Iamaguti et al. 2015). No measurements were conducted on the days that precipitations coincided with the assessment time. However, soil $\mathrm{CO}_{2}$ emission was conducted when precipitations occurred on the afternoon of the day before the measurements.

Soil $\mathrm{CO}_{2}$ emission was measured using an LI-8100A system (LI-COR, Lincoln, NE, USA), which consists of a closed chamber with an internal volume of $854.2 \mathrm{~cm}^{3}$ and a soil contact area of $83.7 \mathrm{~cm}^{2}$. The chamber was coupled to PVC collars, which presented a diameter of $0.10 \mathrm{~m}$, a height of $0.05 \mathrm{~m}$, and were inserted $0.03 \mathrm{~mm}$ deep in the soil. This system analyzes the $\mathrm{CO}_{2}$ concentration in the closed chamber using optical absorption spectroscopy in the infrared spectrum (infrared gas analyzer (IRGA)). The total measurement period at each point was $90 \mathrm{~s}$. Simultaneously with the measurements of soil $\mathrm{CO}_{2}$ emission, soil temperature $\left(T_{\text {soil }}\right)$ and soil moisture $\left(M_{\text {soil }}\right)$ were determined. $T_{\text {soil }}$ was monitored using a temperature sensor, which contained a $0.12-\mathrm{m}$ probe that was inserted into the soil near the PVC collars. In its turn, $M_{\text {soil }}$ was obtained using a Time Domain Reflectometry (TDR) system (Hydrosense TM, Campbell Scientific Inc., Logan, UT, USA), which was inserted into the soil in the layer of 0.0 to $0.12 \mathrm{~m}$, also near the PVC collars. Precipitation was measured daily by plastic rain gauges installed at both sites. For the Oxisol, precipitations occurred in the afternoon of the fourth $(10 \mathrm{~mm})$, fifth $(35 \mathrm{~mm})$, sixth $(2 \mathrm{~mm})$, seventh $(6 \mathrm{~mm})$, eighth $(51 \mathrm{~mm})$, and 11th $(45 \mathrm{~mm})$ days after tillage. In its turn, in the Ultisol, precipitations occurred in the afternoon of day $0(28 \mathrm{~mm}), 2(6 \mathrm{~mm}), 6(45 \mathrm{~mm}), 9(13 \mathrm{~mm})$, and $10(6 \mathrm{~mm})$.

\subsection{Data processing and statistical analysis}

Mean comparison of soil attributes was performed using the 95\% confidence interval described by Gabriel (1978) and processed in the program STATISTICA 7.0 (StatSoft Inc., Tulsa, OK, USA). The multiple regression analysis was performed using the SAS system version 9.1 (SAS Institute, Cary, NC, USA) (SAS Institute 1987) for CPR and CTA by using the stepwise method of variable selection. Thus, this method was applied in each area with different chiseling, for different subsets of attributes, soil temperature, and soil moisture. In this method, a significance level of $10 \%(p=0.10)$ was used in the $F$ test in order to choose the variables for the model. In addition, simultaneously with the statistical analyses, the basic assumptions of the analysis of variance, multiple regression, error normality, variance homogeneity, additivity, and error independence were tested for the assessed attributes. The accumulated soil $\mathrm{CO}_{2}$ emission over the study period was estimated by the area under the emission curve by using the software R (R Development Core Team 2011). 


\section{Results and discussion}

\subsection{Soil $\mathrm{CO}_{2}$ emission and soil attributes in the Oxisol}

The lowest average value of soil $\mathrm{CO}_{2}$ emission $\left(2.8 \mu \mathrm{mol} \mathrm{m} \mathrm{m}^{-2} \mathrm{~s}^{-1}\right)$ was observed in CPR whereas its highest value $\left(3.4 \mu \mathrm{mol} \mathrm{m} \mathrm{m}^{-2} \mathrm{~s}^{-1}\right)$ was observed in CTA (Fig. 1). This is due to the smaller area of soil mobilized by the chiseling in the planting row when compared to the chiseling in total area, hampering gas diffusion, i.e., the entry of $\mathrm{O}_{2}$ into the soil and the release of $\mathrm{CO}_{2}$ to the atmosphere. Thus, the exposure of soil organic matter to microbiological attack contributes to this process of increasing its mineralization (Schwartz et al. 2010), mainly in agricultural practices that promote a greater soil mobilization.

La Scala et al. (2006) observed that the conventional (plowing + harrowing) and reduced (chiseling) tillage systems favored an increase in soil $\mathrm{CO}_{2}$ emission when compared to the soil without tillage. Iamaguti et al. (2015) also observed in an Oxisol that the conventional tillage presented a higher average value of soil $\mathrm{CO}_{2}$ emission when compared to the conventional subsoiling and localized subsoiling. According to the authors, this fact shows that soil $\mathrm{CO}_{2}$ emission is a complex phenomenon and its understanding is challenging due to the great variability of this variable.

The lower soil $\mathrm{CO}_{2}$ emission in the Oxisol under CPR is also due to the lower decomposition rate of organic carbon present in the planting row when compared to CTA, which is
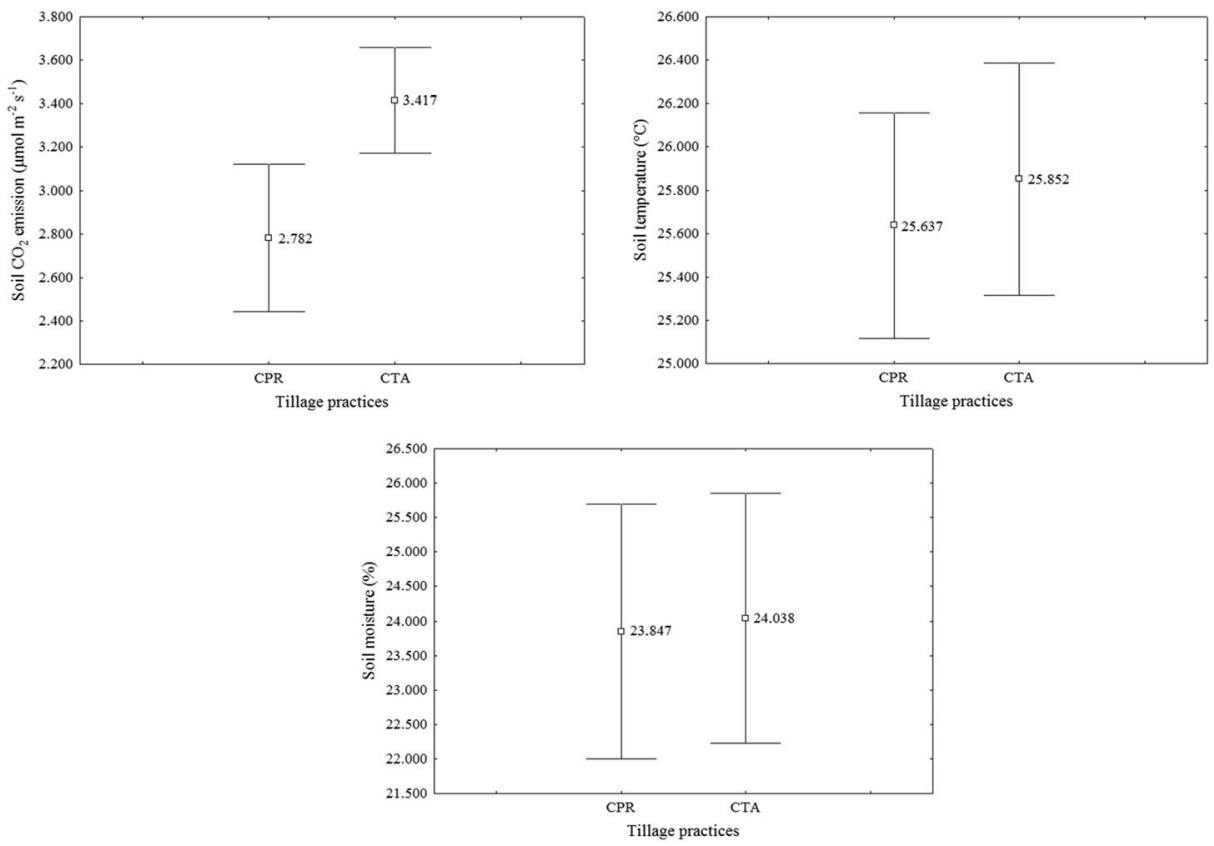

Fig. 1 Average values of soil $\mathrm{CO}_{2}$ emission, soil temperature, and soil moisture as a function of chiseling in the planting row (CPR) and chiseling in total area (CTA) in the Oxisol. Vertical bars indicate the confidence interval. When upper and/or lower limits of the confidence interval overlap, no statistically significant difference $(p<0.05)$ is observed between CPR and CTA 
explained by the smaller mobilized area provided by CPR since chiseling occurred only in the planting row, favoring a smaller soil disaggregation. Thus, the soil submitted to CPR presents a higher capacity to store and conserve soil carbon when compared to that submitted to CTA. In addition, CTA provided a greater soil disaggregation, unprotecting POC and favoring soil microbial activity.

POC differed as a function of chiseling, i.e., CPR presented lower values $\left(2.8 \mathrm{~g} \mathrm{~kg}^{-1}\right)$ when compared to CTA (4.8 $\mathrm{g} \mathrm{kg}^{-1}$ ) (Fig. 2). This behavior may have occurred due to the mineralization of organic carbon that was readily oxidizable in the area under CTA, since its decomposition leads to an increase in soil $\mathrm{CO}_{2}$ emission. In addition, in the tillage systems where the soil is mobilized more intensely, organic matter is distributed in the arable layer, favoring its decomposition. CPR and CTA did not affect soil temperature and soil moisture (Fig. 1) because these variables are not normally limiting in tropical regions. Furthermore, CPR and CTA did not affect OCAM (Fig. 2). This organic matter fraction is related to the particles of silt and clay, which is under colloidal protection (Christensen 1996).

Moreover, soil tillage (CPR and CTA) did not affect the pore classes C1, C2, and C3 (Fig. $3)$. However, a statistical difference $(p<0.05)$ was observed for the pore class $\mathrm{C} 4$, whose lower average value $\left(0.332 \mathrm{~m}^{3} \mathrm{~m}^{-3}\right)$ was observed in CPR comparatively to CTA $\left(0.395 \mathrm{~m}^{3} \mathrm{~m}^{-3}\right)$ (Fig. 3). This result may be due to the greater disaggregation that occurred in CTA, leading to a higher compression of soil particles, disaggregating the largest pores and contributing to the formation of small pores. In a clayey soil whose structure was changed, Souza and Alves (2003) observed that the spaces occupied by large pores were affected by an increase in the mass of soil particles per unit volume, favoring the formation of small pores.

Chiseling in the planting row is a characteristic of the recent management techniques adopted by the sugarcane sector, in which soil mobilization occurs in a localized and combined manner by using agricultural implements that simultaneously perform deep subsoiling, application and incorporation of soil correctives, straw windrowing, and soil declodding, such as in bed formation. When soil tillage occurs localized in the planting row, machinery traffic occurs in a controlled manner, providing a lower accumulation of contact pressures generated by the wheels of agricultural machines, which contributes to reduce soil compaction and leads to production, reducing the operational cost related to soil tillage by up to $30 \%$ (Souza et al. 2014). In addition, the localized soil tillage leads to a reduction in fuel consumption and hence in greenhouse gas emissions associated with fuel burning. Thus, management practices related
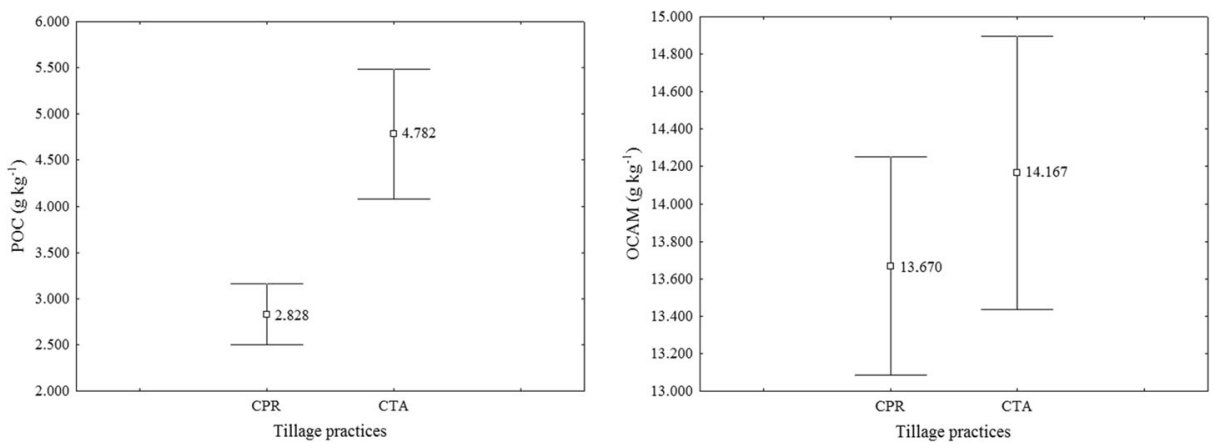

Fig. 2 Average values of particulate organic carbon (POC) and organic carbon associated with minerals (OCAM) as a function of chiseling in the planting row (CPR) and chiseling in total area (CTA) in the Oxisol. Vertical bars indicate the confidence interval. When upper and/or lower limits of the confidence interval overlap, no statistically significant difference $(p<0.05)$ is observed between CPR and CTA 

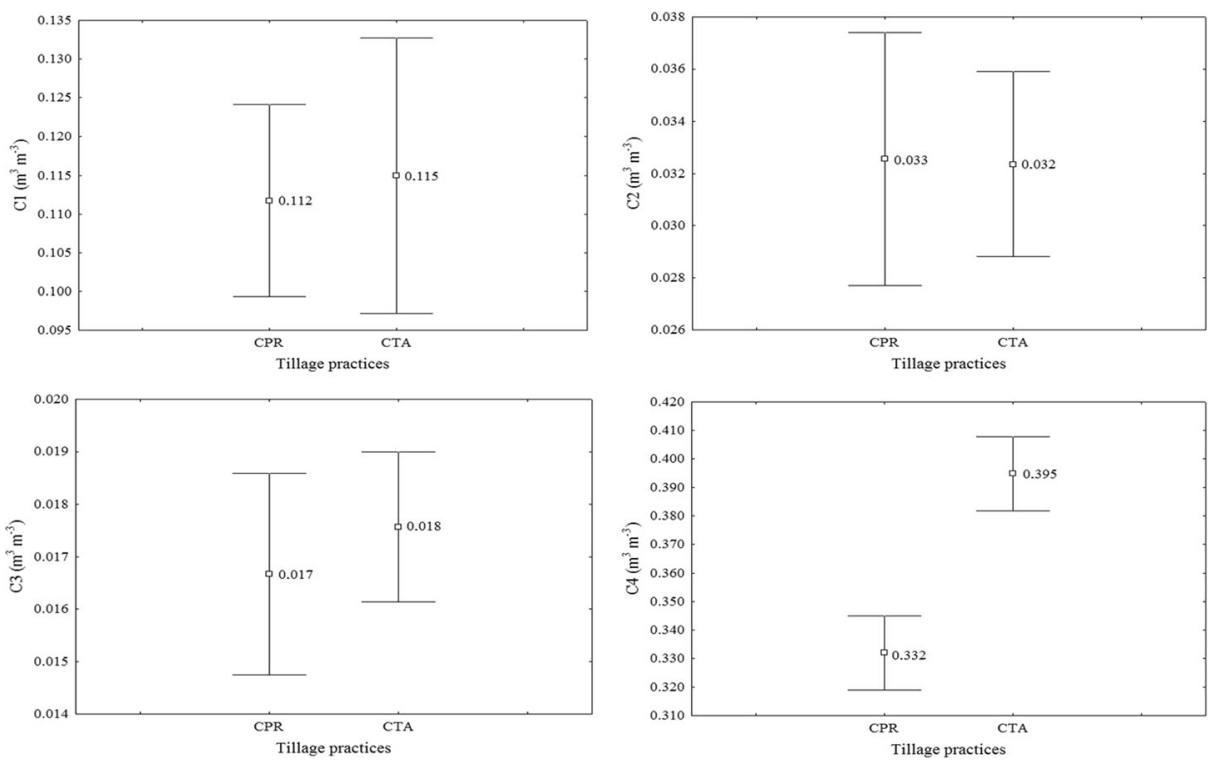

Fig. 3 Average values of water volume $\left(\mathrm{m}^{3} \mathrm{~m}^{-3}\right)$ corresponding to $\mathrm{C} 1(\phi \geq 0.1 \mathrm{~mm}), \mathrm{C} 2(0.05 \leq \phi<0.1 \mathrm{~mm}), \mathrm{C} 3$ $(0.0375 \leq \phi<0.05 \mathrm{~mm})$, and $\mathrm{C} 4(\phi<0.0375 \mathrm{~mm})$ as a function of chiseling in the planting row (CPR) and chiseling in total area (CTA) in the Oxisol. Vertical bars indicate the confidence interval. When upper and/or lower limits of the confidence interval overlap, no statistically significant difference $(p<0.05)$ is observed between CPR and CTA

to localized soil tillage for sugarcane planting are effective strategies for mitigating greenhouse gas emissions in agriculture, allowing sugarcane to increasingly stand out as an environmentally viable energy matrix.

In order to understand the behavior of soil $\mathrm{CO}_{2}$ emission as a function of the studied soil attributes, a multiple regression analysis was performed for each soil tillage considering both soil classes. Multiple regression models showed that OCAM and C2 explained $72 \%$ of the variability of soil $\mathrm{CO}_{2}$ emission $\left(R^{2}=0.72\right)$ (Table 1$)$. In addition, the parameters estimated by the multiple regression for OCAM and $\mathrm{C} 2$ were positive, indicating individual correlations between these variables and soil $\mathrm{CO}_{2}$ emission in $\mathrm{CPR}$, i.e., as OCAM and $\mathrm{C} 2$ increased soil $\mathrm{CO}_{2}$ emission also increased. This positive signal for both variables may be related to the larger pores, which favor an increase in soil $\mathrm{CO}_{2}$ flux. Chiseling in the planting row leads to a less soil mobilization, favoring OCAM protection and preserving larger pores such as $\mathrm{C} 2$. This result occurred, because the area under CPR preserved the large pores. Moreover, although OCAM has less exposure, the microorganisms act in its decomposition, favoring the emission of $\mathrm{CO}_{2}$ through the pores.

Chiseling in the planting row and in total area initially increase soil $\mathrm{CO}_{2}$ emission due to soil disaggregation, which favors the mineralization of carbon that was physically protected in the aggregates (Schwartz et al. 2010). Thus, soil management systems that provide a reduction in $\mathrm{CO}_{2}$ emissions present a greater potential for soil carbon conservation when compared to systems with a higher $\mathrm{CO}_{2}$ emission (Costa et al. 2008). In addition, larger pores favor an 
environment with a high oxygenation for $\mathrm{CO}_{2}$ production by microorganisms. In our study, CTA mobilized a larger area, creating an environment that favored both microbial activity and particle accommodation, leading to the formation of small pores, although they did not govern soil $\mathrm{CO}_{2}$ emission in $\mathrm{CPR}$.

Multiple regression models for CTA showed that $M_{\text {soil }}$ and $T_{\text {soil }}$ explained $53 \%$ of the variability of soil $\mathrm{CO}_{2}$ emission $\left(R^{2}=0.53\right)$ (Table 2$)$. In this case, CTA provided a greater soil disaggregation, causing the soil $\mathrm{CO}_{2}$ emission to be influenced only by soil moisture and soil temperature. The parameters estimated in this analysis for $M_{\text {soil }}$ and $T_{\text {soil }}$ were also positive, showing individual correlations between these variables and soil $\mathrm{CO}_{2}$ emission. Soil $\mathrm{CO}_{2}$ emission was related to $M_{\text {soil }}$ and $T_{\text {soil }}$ only in CTA, since this tillage operation promotes a greater soil disturbance and affects both variables, which are directly related to each other and sensitive to soil structure modification. In a study conducted in an Oxisol under conventional (plowing + harrowing) and reduced (chiseling) tillage systems, La Scala et al. (2006) also observed a positive correlation between soil $\mathrm{CO}_{2}$ emission and soil moisture, but not significant with soil temperature. Iamaguti et al. (2015) found a significant and negative correlation between soil $\mathrm{CO}_{2}$ emission and soil temperature for conventional tillage, different from that observed in our study. In addition, these authors did not find a correlation between soil $\mathrm{CO}_{2}$ emission and soil moisture in the conventional tillage (two harrowing), conventional subsoiling (subsoiling in total area), and localized subsoiling (subsoiling in the planting row). Ussiri and Lal (2009) observed a significant and positive correlation between soil temperature and soil $\mathrm{CO}_{2}$ emission after soil tillage (moldboard plowing, chiseling, and no tillage).

The total soil $\mathrm{CO}_{2}$ emission accumulated in the Oxisol was calculated and presented a value of $1336.3 \mathrm{~kg} \mathrm{CO}_{2} \mathrm{ha}^{-1}$ for CTA and $1042.6 \mathrm{~kg} \mathrm{CO}_{2} \mathrm{ha}^{-1}$ for CPR. Thus, CTA emitted, from soil to the atmosphere, $293.7 \mathrm{~kg} \mathrm{CO}_{2} \mathrm{ha}^{-1}$ more than CPR in a 12-day period, which is equivalent to a loss of $80 \mathrm{~kg} \mathrm{C}^{-1}\left(\mathrm{C}-\mathrm{CO}_{2}\right)$ due to a greater soil mobilization in CTA. Oxisols and Ultisols occupy $58 \%$ of the total area of Brazil, $32 \%$ of which represented only by Oxisols (Santos et al. 2013). Thus, determining soil management that reduces carbon loss is essential in the face of the challenges of global agriculture to increase the efficiency of conventional management practices, integrating and/or replacing them with more sustainable alternatives (FAO 2014) since carbon loss is detrimental both due to environmental factors related to climate change and to agronomic factors related to the decrease of organic matter that affects the structure and fertility of soils and, consequently, food production.

\subsection{Soil $\mathrm{CO}_{2}$ emission and soil attributes in the Ultisol}

In the Ultisol, soil tillage (CPR and CTA) did not affect soil $\mathrm{CO}_{2}$ emission, $T_{\text {soil }}, M_{\text {soil }}$, OCAM, POC (Figs. 4 and 5), C1, C2, C3, and C4 (Fig. 6). This difference may be due to the higher

Table 2 Multiple regression model of the average soil $\mathrm{CO}_{2}$ emission as a function of soil attributes in the chiseling in total area (CTA) in the Oxisol

\begin{tabular}{lrllr}
\hline Attribute & Parameter & SE & $p$ & $R^{2}$ \\
\hline Intercept & -13.54845 & 5.21824 & 0.0267 & \\
$M_{\text {soil }}$ & 0.10843 & 0.04438 & 0.0347 & 0.2826 \\
$T_{\text {soil }}$ & 0.55328 & 0.16707 & 0.0079 & 0.5265 \\
\hline
\end{tabular}

$\mathrm{SE}=$ standard error of the parameter estimation; $R^{2}=$ coefficient of determination; $M_{\text {soil }}=$ soil moisture; $T_{\text {soil }}=$ soil temperature 
sand content $\left(809.30 \mathrm{~g} \mathrm{~kg}^{-1}\right)$ and Ds $\left(1.71 \mathrm{~g} \mathrm{~cm}^{-3}\right)$ and the lower MWD $(1.72 \mathrm{~mm}), \mathrm{Pt}$ $\left(0.32 \mathrm{~m}^{3} \mathrm{~m}^{-3}\right)$, Macro $\left(0.07 \mathrm{~m}^{3} \mathrm{~m}^{-3}\right)$, Micro $\left(0.25 \mathrm{~m}^{3} \mathrm{~m}^{-3}\right)$, and OC $\left(7.00 \mathrm{~g} \mathrm{~kg}^{-1}\right)$ found in the Ultisol when compared to the sand content (392.00 $\left.\mathrm{g} \mathrm{kg}^{-1}\right)$, Ds $\left(1.24 \mathrm{~g} \mathrm{~cm}^{-3}\right)$, MWD $(3,46 \mathrm{~mm})$, Pt $\left(0.53 \mathrm{~m}^{3} \mathrm{~m}^{-3}\right)$, Macro $\left(0.15 \mathrm{~m}^{3} \mathrm{~m}^{-3}\right)$, Micro $\left(0.38 \mathrm{~m}^{3} \mathrm{~m}^{-3}\right)$, and OC (17.94 $\mathrm{g} \mathrm{kg}^{-1}$ ) found in the Oxisol. When studying the attributes of a soil submitted to chiseling in the planting row and in total area in the same experimental area of our study, Souza (2016) observed a higher soil density in the Ultisol for both chiseling (CPR of $1.73 \mathrm{~g} \mathrm{~cm}^{-3}$ and CTA of $1.69 \mathrm{~g} \mathrm{~cm}^{-3}$ ) when compared to the Oxisol (CPR of $1.30 \mathrm{~g} \mathrm{~cm}^{-3}$ and CTA of $\left.1.18 \mathrm{~g} \mathrm{~cm}^{-3}\right)$. Moreover, this author observed lower values of soil porosity in the Ultisol (CPR of $0.31 \mathrm{~m}^{3} \mathrm{~m}^{-3}$ and CTA of $0.33 \mathrm{~m}^{3} \mathrm{~m}^{-3}$ ) when compared to the Oxisol (CPR of $0.49 \mathrm{~m}^{3} \mathrm{~m}^{-3}$ and CTA of $0.56 \mathrm{~m}^{3} \mathrm{~m}^{-3}$ ) at a depth of $0-0.10 \mathrm{~m}$. Sandy textured soils favor a porosity decrease, leading to a reduction in soil $\mathrm{CO}_{2}$ diffusion (Shestak and Busse 2005), since a lower total porosity provides an anaerobic environment (with little oxygenation), restricting soil microbial activity.

Li et al. (2002) observed that at environments with low porosity and oxygenation, there is a decrease of up to one third of the number of microorganisms that live in the soil (bacteria and fungi), thus reducing the emission of $\mathrm{CO}_{2}$ to the atmosphere. Da Silva et al. (2004) assessed the physical attributes of an Ultisol under different soil tillage (conventional tillage, reduced tillage, and no tillage) and verified that soil disturbance did not influence attributes such as pore size distribution and total porosity. In addition, in the Ultisol, the average values of soil $\mathrm{CO}_{2}$ emission were not significant. This result is probably due to the intrinsic characteristics of
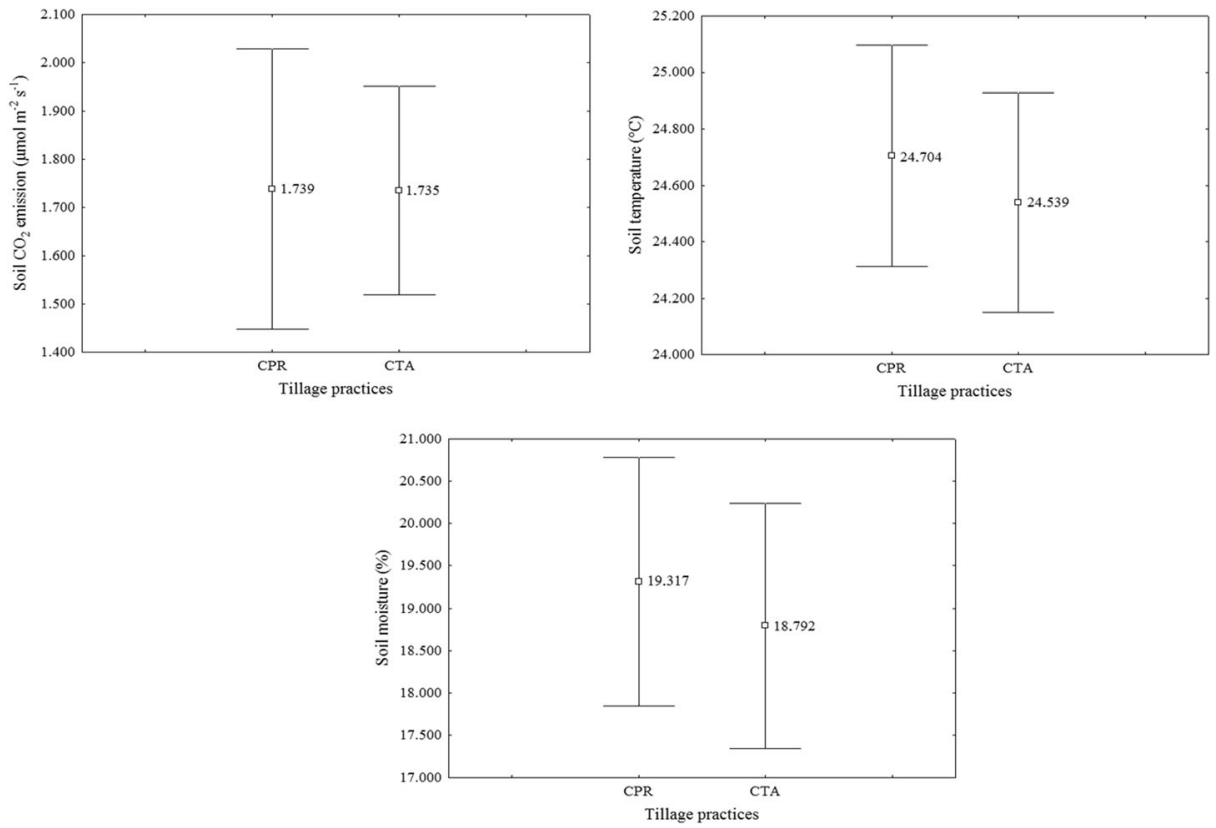

Fig. 4 Average values of soil $\mathrm{CO}_{2}$ emission, soil temperature, and soil moisture as a function of chiseling in the planting row (CPR) and chiseling in total area (CTA) in the Ultisol. Vertical bars indicate the confidence interval. When upper and/or lower limits of the confidence interval overlap, no statistically significant difference $(p<0.05)$ is observed between CPR and CTA 

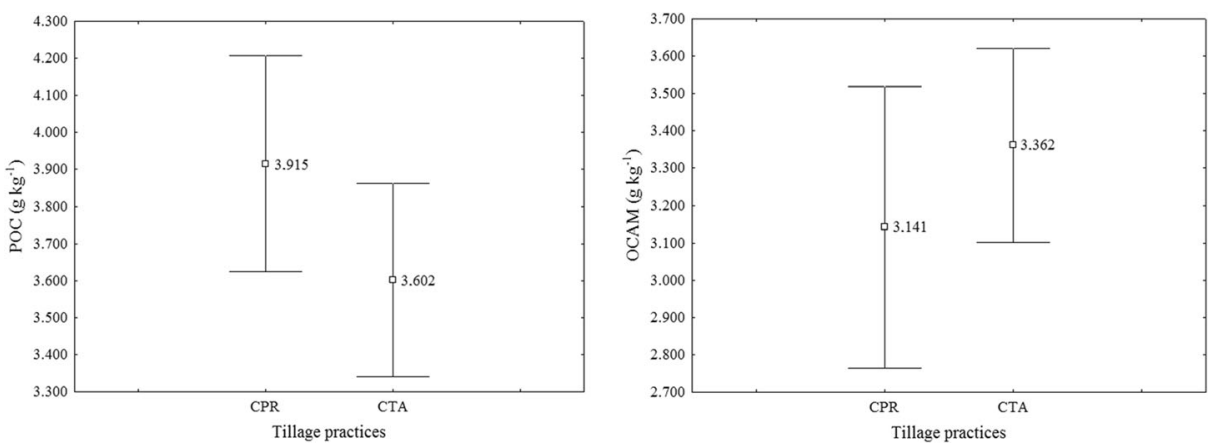

Fig. 5 Average values of particulate organic carbon (POC) and organic carbon associated with minerals (OCAM) as a function of chiseling in the planting row (CPR) and chiseling in total area (CTA) in the Ultisol. Vertical bars indicate the confidence interval. When upper and/or lower limits of the confidence interval overlap, no statistically significant difference $(p<0.05)$ is observed between CPR and CTA

the Ultisol, because soils that present a sandy texture in the superficial layer can promote a greater particle reorganization, with reduced pore volumes, and are more resistant to external forces (Braga et al. 2015).

The Ultisol presented lower values of OC when compared to the Oxisol, resulting in lower average values of soil $\mathrm{CO}_{2}$ emission in CPR and CTA. In general, the Oxisol presents a greater
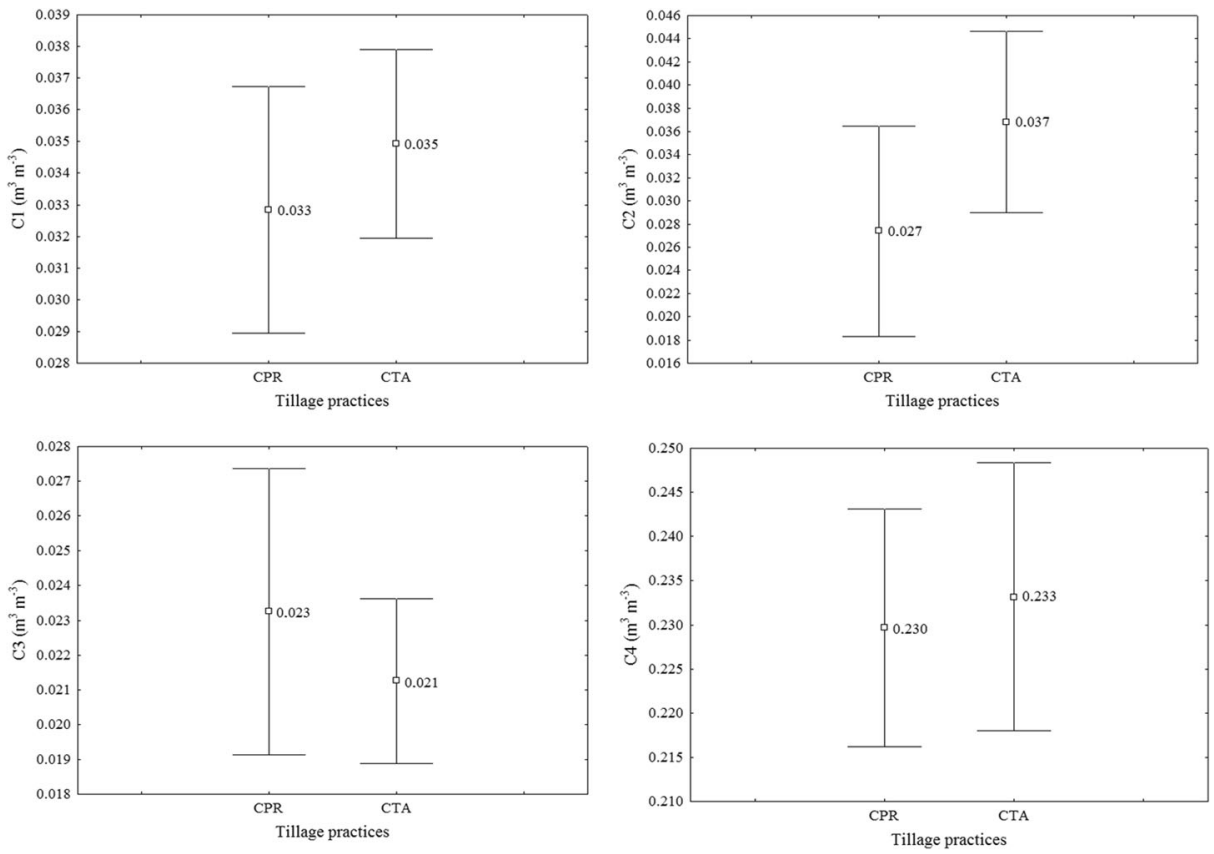

Fig. 6 Average values of water volume $\left(\mathrm{m}^{3} \mathrm{~m}^{-3}\right)$ corresponding to $\mathrm{C} 1(\phi \geq 0.1 \mathrm{~mm}), \mathrm{C} 2(0.05 \leq \phi<0.1 \mathrm{~mm}), \mathrm{C} 3$ $(0.0375 \leq \phi<0.05 \mathrm{~mm})$, and $\mathrm{C} 4(\phi<0.0375 \mathrm{~mm})$ as a function of chiseling in the planting row (CPR) and chiseling in total area (CTA) in the Ultisol. Vertical bars indicate the confidence interval. When upper and/or lower limits of the confidence interval overlap, no statistically significant difference $(p<0.05)$ is observed between CPR and CTA 
physical protection to the organic matter inside its aggregates, reducing the microbial activity and hence the mineralization of organic residues in the soil, in addition to favoring an increase in its carbon stock.

No significant difference was observed for the average values of soil $\mathrm{CO}_{2}$ emission and tillage operations in the Ultisol. However, by calculating the total soil $\mathrm{CO}_{2}$ emission accumulated over the assessment period and comparing CTA (702.8 $\mathrm{kg} \mathrm{CO}_{2} \mathrm{ha}^{-1}$ ) and CPR (659.1 $\mathrm{kg} \mathrm{CO}_{2} \mathrm{ha}^{-1}$ ), an additional emission of $43.7 \mathrm{~kg} \mathrm{CO}_{2} \mathrm{ha}^{-1}$ was observed in only 11 days of assessments, i.e., a loss of $12 \mathrm{~kg} \mathrm{C} \mathrm{ha}^{-1}\left(\mathrm{C}-\mathrm{CO}_{2}\right)$ occurred in this short period due to the more intense soil mobilization in CTA. Therefore, considering that the Ultisol naturally presents a lower carbon content due to its sandy texture when compared to the Oxisol, which presents a more clayey texture, any carbon loss can be considered significant and may have a consequence on its soil structure.

In the multiple regression analysis, $M_{\text {soil }}, \mathrm{C} 1$, and OCAM explained $82 \%\left(R^{2}=0.82\right)$ of the variability of soil $\mathrm{CO}_{2}$ emission in CPR (Table 3) whereas, in CTA, $M_{\text {soil }}$, OCAM, and POC explained $67 \%\left(R^{2}=0.67\right)$ of this variability (Table 4$)$. The greater soil disaggregation provided by CTA explains the lower variability of soil $\mathrm{CO}_{2}$ emission when compared to CPR, since a greater disaggregation favors a good environment for microbial activity, leading to the organic matter decomposition and favoring carbon loss as $\mathrm{CO}_{2}$. Thus, in CPR and CTA, $M_{\text {soil }}$ is negatively related to soil $\mathrm{CO}_{2}$ emission, which is possibly due to the occurrence of rain in the experimental area over the experimental period. According to Lier (2001), an increase in soil moisture reduces the flow of gases in the soil. When studying soil $\mathrm{CO}_{2}$ emission in an Ultisol at a depth of 0-0.05 $\mathrm{m}$ under conventional (plowing + harrowing) and no-tillage systems, Costa et al. (2008) also found similar results. La Scala et al. (2006) also found similar results.

Furthermore, OCAM and $\mathrm{C} 1$ were positively related to soil $\mathrm{CO}_{2}$ emission in $\mathrm{CPR}$. In this case, a less soil mobilization led to a greater preservation of larger pores and OCAM. Large pores favor the flow of gases in the soil, contributing to soil $\mathrm{CO}_{2}$ emission. In addition, OCAM is a source of energy for microorganisms, favoring the emission of carbon as $\mathrm{CO}_{2}$. OCAM and POC were negatively related to soil $\mathrm{CO}_{2}$ emission in CTA. Although chiseling in the planting row and in total area are not distinct from each other, CTA provides a greater soil mobilization when compared to CPR. Sandy textured soils provide a low binding power of the organic constituents with colloidal components, resulting in a less physical protection of the organic matter, which favors a greater decomposition by microorganisms (Bayer et al. 2000). Thus, soil $\mathrm{CO}_{2}$ emission is favored by the mineralization of organic matter that was unprotected due to the rupture of aggregates caused by chiseling.

In our study, the Ultisol presented a higher average value of Ds $\left(1.71 \mathrm{~g} \mathrm{~cm}^{-3}\right)$ and lower average values of $\operatorname{Pt}\left(0.32 \mathrm{~m}^{3} \mathrm{~m}^{-3}\right)$, Macro $\left(0.07 \mathrm{~m}^{3} \mathrm{~m}^{-3}\right)$, Micro $\left(0.25 \mathrm{~m}^{3} \mathrm{~m}^{-3}\right)$, and OC $\left(7.00 \mathrm{~g} \mathrm{~kg}^{-1}\right)$ when

Table 3 Multiple regression model of the average soil $\mathrm{CO}_{2}$ emission as a function of soil attributes in the chiseling in the planting row (CPR) in the Ultisol

\begin{tabular}{lrrrr}
\hline Attribute & Parameter & SE & $p$ & $R^{2}$ \\
\hline Intercept & 3.06366 & 0.73855 & 0.0014 & 0.5583 \\
$M_{\text {soil }}$ & -0.16642 & 0.02816 & $<0.0001$ & 0.7204 \\
C1 & 29.17442 & 9.28408 & 0.0085 & 0.8164 \\
OCAM & 0.29565 & 0.11802 & 0.0277 & \\
\hline
\end{tabular}

$\mathrm{SE}=$ standard error of the parameter estimation; $R^{2}=$ coefficient of determination; $M_{\text {soil }}=$ soil moisture; $\mathrm{C} 1(\phi \geq$ $0.1 \mathrm{~mm})$; OCAM = organic carbon associated with minerals 
Table 4 Multiple regression model of the average soil $\mathrm{CO}_{2}$ emission as a function of soil attributes in the chiseling in total area (CTA) in the Ultisol

\begin{tabular}{lrrrr}
\hline Attribute & Parameter & SE & $p$ & $R^{2}$ \\
\hline Intercept & 5.88067 & 0.86838 & $<0.0001$ & 0.4084 \\
$M_{\text {soil }}$ & -0.09494 & 0.02539 & 0.0025 & 0.5670 \\
OCAM & -0.39862 & 0.13997 & 0.0137 & 0.6701 \\
POC & -0.26623 & 0.13210 & 0.0450 & \\
\hline
\end{tabular}

$\mathrm{SE}=$ standard error of the parameter estimation; $R^{2}=$ coefficient of determination; $M_{\text {soil }}=$ soil moisture; OCAM $=$ organic carbon associated with minerals; POC $=$ particulate organic carbon

compared to the Oxisol (Ds of $1.24 \mathrm{~g} \mathrm{~cm}^{-3}$, Pt of $0.32 \mathrm{~m}^{3} \mathrm{~m}^{-3}$, Macro of $0.15 \mathrm{~m}^{3} \mathrm{~m}^{-3}$, Micro of $0.38 \mathrm{~m}^{3} \mathrm{~m}^{-3}$, and $\mathrm{OC}$ of $17.94 \mathrm{~g} \mathrm{~kg}^{-1}$ ). This result could explain the lower soil $\mathrm{CO}_{2}$ emission in the Ultisol since higher values of soil bulk density and a low total porosity favor an environment with little oxygenation, limiting soil microbial activity. In addition, the Ultisol presents a less aggregation, i.e., the aggregates are broken easily because of their less stable structure. Thus, with aggregate disruption, carbon is released as $\mathrm{CO}_{2}$, leading to a lower soil $\mathrm{CO}_{2}$ emission in the Ultisol. This behavior can also be explained by the higher content of $\mathrm{Fe}_{\mathrm{d}}\left(80.32 \mathrm{~g} \mathrm{~kg}^{-1}\right)$ found in the Oxisol when compared to the Ultisol $\left(18.5 \mathrm{~g} \mathrm{~kg}^{-1}\right)$. Clayey textured soils, with high contents of Fe and Al oxides and hydroxides, contribute to increasing organic carbon stability in the form of organomineral complexes (Roscoe and Buurman 2003).

Another factor that may explain the lower soil $\mathrm{CO}_{2}$ emission in the Ultisol is the low microporosity when compared to the Oxisol. This low microporosity reduces water adsorption in the pores, making it an environment limiting for the survival of microorganisms that act in the organic matter decomposition, because water is essential for their life. Thus, as the microbial activity decreases, carbon loss in the form of $\mathrm{CO}_{2}$ also decreases. Souza et al. (2017) studied soil $\mathrm{CO}_{2}$ emission in an Oxisol and Ultisol and observed that the total soil $\mathrm{CO}_{2}$ emission was, on average, higher in the Oxisol (1178.60 $\left.\mathrm{kg} \mathrm{CO}_{2} \mathrm{ha}^{-1}\right)$ when compared to the Ultisol (618.15 $\left.\mathrm{kg} \mathrm{CO}_{2} \mathrm{ha}^{-1}\right)$.

Soil $\mathrm{CO}_{2}$ emission presents a different behavior as a function of soil texture, soil management, and climatic conditions due to its variability and dependence of climatic conditions of each environment by the variables that are involved in both $\mathrm{CO}_{2}$ production and emission processes. Thus, more studies are needed to understand the behavior of soil $\mathrm{CO}_{2}$ emission in different soil textural classes, soil management, and climatic conditions since its characterization is challenging due to its great variability.

\section{Conclusions}

In the Oxisol, chiseling in planting row and in total area directly affected soil structure, causing changes in soil porosity and in soil $\mathrm{CO}_{2}$ emission. On the other hand, in the Ultisol, soil $\mathrm{CO}_{2}$ emission was not affected regardless of the chiseling.

Chiseling in the planting row favored the formation of small pores in the Oxisol, contributing to a reduction in soil $\mathrm{CO}_{2}$ emission. In the Ultisol, soil pores did not influence soil $\mathrm{CO}_{2}$ emission regardless of the chiseling.

In the chiseling in planting row, macropores and organic carbon associated with minerals interfered with soil $\mathrm{CO}_{2}$ emission in the Oxisol whereas, in the Ultisol, macropores, soil moisture, and organic carbon associated with minerals interfered with soil $\mathrm{CO}_{2}$ emission. 
The results indicate that in addition to soil tillage intensity, soil texture to which the tillage operation will be applied must be taken into account in the adoption of soil management strategies aiming at reducing greenhouse gas emissions. Thus, in order to mitigate $\mathrm{CO}_{2}$ emission and, consequently, carbon preservation, agricultural soils that present a more clayey texture require tillage practices that allow less mobilization when compared to soils with a more sandy texture. Improved soil management practices and strategies can help address a variety of global change challenges.

Funding information To the Graduate Program in Agronomy (Soil Science) of the São Paulo State University (FCAV-UNESP) and to the Coordination for the Improvement of Higher Education Personnel (CAPES) and the São Paulo Research Foundation (FAPESP) for the financial support (process no. 2014/14490-2).

\section{References}

Bayer C, Mielniczuk J, Martin-Neto L (2000) Efeitos de sistemas de preparo e de cultura na dinâmica da matéria orgânica e na mitigação das emissões de $\mathrm{CO}_{2}$. R Bras Ci Solo 24:599-607. https://doi.org/10.1590/S010006832000000300013

BradyNC, WeilRR (2013) Elementos da natureza e propriedades dos solos. Porto Alegre

Braga FVA, Reichert JM, Mentges MI, Vogelmann ES, Padrón RAR (2015) Propriedades mecânicas e permeabilidade ao ar em topossequência Argissolo-Gleissolo: Variação no perfil e efeito de compressão. R Bras Ci Solo 39:1025-1035. https://doi.org/10.1590/01000683rbes20140724

Cambardella CA, Elliott ET (1992) Particulate soil organic-matter changes across a grassland cultivation sequence. Soil Sci Soc Am J 56:777-783. https://doi.org/10.2136/sssaj1992.03615995005600030017x

Cerri CC, Cerri CEP (2007) Agricultura e aquecimento global Boletim Informativo de Sociedade Brasileira da Ciência do Solo 32:40-44

Christensen BT (1996) Carbon in primary and secondary organomineral complexes. In: Carter MR, Stewart BA (eds) Structure and organic matter storage in agricultural soils. Boca Raton, CRC Lewis, pp 97-165

Claessen MEC (1997) Manual de métodos de análise de solo. Centro Nacional de Pesquisa de Solos, Rio de Janeiro

Costa FS, Bayer C, Zanatta JA, Mielniczuk J (2008) Estoque de carbono orgânico no solo e emissões de dióxido de carbono influenciadas por sistemas de manejo no sul do Brasil. Rev Bras Ci Solo 32:323-332. https://doi. org/10.1590/S0100-06832008000100030

Da Silva MAS, Mafra AL, Albuquerque JA, Bayer C, Mielniczuk J (2004) Atributos físicos do solo relacionados ao armazenamento de água em um Argissolo Vermelho sob diferentessistemas de preparo. C Rural 35:544 552. https://doi.org/10.1590/S0103-84782005000300009

Fao - Food and Agriculture Organization of the United Nations. Statistics Division. (2014) Disponível em: $<$ http://faostat3.fao.org/download/Q/QC/E >. Acesso em: 10 nov 2017

Gabriel KA (1978) Simple method of multiple comparisons of means. J Am Stat Assoc 73(364):724-729. https://doi.org/10.2307/2286265

Iamaguti JL, Moitinho MR, Teixeira DDB, Bicalho ES, Panosso AR, La Scala N (2015) Preparo do solo e emissão de $\mathrm{CO}_{2}$, temperatura e umidade do solo em área canavieira. Rev Bras Eng Agr Amb 19:497-504. https://doi.org/10.1590/1807-1929/agriambi.v19n5p497-504

IPCC - Intergovernmental Panel on Climate Change (2014) Climate Change2014: Synthesis Report. Contribution of Working Groups I, II and III to the Fifth Assessment Report of the Intergovernmental Panel on Climate Change [Core Writing Team, Pachauri RK, Meyer LA (eds.)]. IPCC, Geneva, pp 151

IPT -Instituto de Pesquisas Tecnológicas do Estado de São Paulo (1981) Mapa geomorfológico do Estado de São Paulo São Paulo, pp 94

Jackson ML (1985) Soil chemical analysis.2ed. Prentice Hall, Upper Saddle River

La Scala N, Bolonhezi D, Pereira GT (2006) Short-term soil $\mathrm{CO}_{2}$ emission after conventional and reduced tillage of a no-till sugarcane area in southern Brazil. Soil Till Res 91:244-248. https://doi.org/10.1016/j. still.2005.11.012

Lal R (2009) Challenges and opportunities in soil organic matter research. Eur J Soil Sci 60:158-169. https://doi. org/10.1111/j.1365-2389.2008.01114.x

Li X, Inubushi K, Sakamoto K (2002) Nitrous oxide concentrations in Andisol profile and emissions to the atmosphere as influenced by the application of nitrogen fertilizers and manure. Biol Fertil Soils 35:108-113. https://doi.org/10.1007/s00374-002-0447-7 
Lier QJV (2001) Oxigenação do sistema radicular: uma abordagem física. Rev Bras Ci Solo 25:233-238. https://doi.org/10.1590/S0100-06832001000100025

Luo L, Lin H, Li S (2010) Quantification of 3-D soil macropore networks in different soil types and land uses using computed tomography. J Hydrol 393:53-64. https://doi.org/10.1016/j.jhydrol.2010.03.031

Mangalassery S, Sjogersten S, Sparkes DL, Sturrock CJ, Mooney SJ (2013) The effect of soil aggregate size on pore structure and its consequence on emission of greenhouse gases. Soil Till Res 132:39-46. https://oi. org/10.1016/j.still.2013.05.003

Mazurana M, Levien R, Müller J, Conte O (2011) Sistemas de preparo de solo: alterações na estrutura do solo e rendimento das culturas. R Bras Ci Solo 35:1197-1206. https://doi.org/10.1590/S0100-06832011000400013

Mehra OP, Jackson ML (1960) Iron oxide removed from soils and clays by dithionite-citrate system buffered with sodium bicarbonate. Clay Clay Miner 7:317-327

Mooney SJ, Morris C (2008) A morphological approach to understanding preferential flow using image analysis with dye tracers and X-ray computed tomography. Catena 73:204-211. https://doi.org/10.1016/j. catena.2007.09.003

Panosso AR, Marques J Jr, Milori DMBP, Ferraudo AS, Barbieri DM, Pereira GT, La Scala N (2011) Soil CO 2 emission and its relation to soil properties in sugarcane areas under slash-and-burn and green harvest. Soil Till Res 111:190-196. https://doi.org/10.1016/j.still.2010.10.002

Perecin D, Ferraudo GM, Azania CAM, Schiavetto AR (2015) Statistical analysis for correlated paired-plot designs. Am J Exp Agric 9:1-7. https://doi.org/10.9734/AJEA/2015/20722

R Development Core Team (2011) R: a language and environment for statistical computing. R Foundation for Statistical Computing, Vienna, Austria. ISBN 3-900051-07-0, URL: http://www.R-project.org/

Roscoe R, Buurman P (2003) Tillage effects on soil organic matter in density fractions of a Cerrado Oxisol. Soil Till Res 70:107-119. https://doi.org/10.1016/S0167-1987(02)00160-5

Santos HG, Jacomine PKT, Anjos LHC, Oliveira VA, Oliveira JB, Coelho MR, Lumbreras JF, Cunha TJF (2013) Sistema brasileiro de classificação de solos, 3rd edn. Embrapa Solos, Rio de Janeiro 353 p

SAS Institute (1987) SAS - Statistical Analysis System: system for elementary statistical analysis. SAS Institute, Cary, p 416

Schwartz RC, Baumhardt RL, Evett SR (2010) Tillage effects on soil water redistribution and bare soil evaporation throughout a season. Soil Till Res 110:221-229. https://doi.org/10.1016/j.still.2010.07.015

Shestak CJ, Busse MD (2005) Compaction alters physical but not biological indices of soil health. Soil Sci Soc Am J 69:236-246. https://doi.org/10.2136/sssaj2005.0236

Souza FCAde (2016) Atributos físicos de solos submetidos à escarificação na linha de plantio e em área total para cultivo da cana-de-açúcar. Dissertação, Faculdade de Ciências Agrárias e Veterinárias

Souza ZM, Alves MC (2003) Propriedades físicas e teor de matéria orgânica em um Latossolo Vermelho de cerrado sob diferentesusos e manejos. Acta Sci Agron 25:27-34

Souza GS, Souza ZM, Silva RB, Barbosa RS, Araújo FS (2014) Effects of traffic control on the soil physical quality and the cultivation of sugarcane. Rev Bras Ciênc Solo 38:135-146

Souza LC, Fernandes C, Nogueira DCS, Moitinho MR, Bicalho ES, La Scala N (2017) Can partial cultivation of only the sugarcane row reduce $\mathrm{CO}_{2}$ emissions in an Oxisol and Ultisol? Agron J 109(3):1113-1121

Teixeira LG, La Scala N, Lopes A (2010) Fluxo de $\mathrm{CO}_{2}$ do solo após aração e escarificação em diferentes configurações. Holos Environ 10(1):1-11

Ussiri AN, Lal R (2009) Long-term tillage effects on soil carbon storage and carbon dioxide emissions in continuous corn cropping system from an alfisol in Ohio. Soil Till Res 104:39-47. https://doi.org/10.1016/j. still.2008.11.008

Zhou X, Lin HS, White EA (2008) Surface soil hydraulic properties in four soil series under different land uses and their temporal changes. Catena 73:180-188. https://doi.org/10.1016/j.catena.2007.09.009 